\title{
The Current Inflation: The United States Experience
}

\author{
ALBET E. BURGER
}

\begin{abstract}
The following paper was presented at the "International Conference on The "New Inflation' and Monetary Policy" held June 24-26, 1974 in Milan, Italy. The Conference was sponsored fointly by Banca Commerciale Italiana and the Department of Economics, Universita Booconi. Professors Gatano Stammati and Innocenzo Gasparin were foint chaimen of the Conference. Papers on inflation and the problems it implies for monetary analysis were presented by Professors John Hicks, Karl Brunner, Franco Modigliani, and Robert A. Mundell. Popers discussing the inflationary experience in specific countries were presented for Brazil, the European Economic Commanity, France, the Federal Republic of Germany, Italy. Japan, the United Kingdom, and the United States.

The authors of individual country papers were asked to direct their comments to specific questions about the inflationary experience in theip countries. The organization and healings of the following paper reflect this procedure. The orsanizers of the Conference are arranging to have the complete proceedings published in the near funtre.
\end{abstract}

I features of the "new infation." First, the current widespread inflation across industrial countries is a "new" inflation only in the sense that it is a phenomenon of the last ten years. The current inflation has not been largely determined by the supply behavior of nonindustrial countries. The basic cause of the current inflation is the same as the cause of all previous inflations - too much money chasing too few goods.

The most disturbing aspect of the current inflation is not that there has been a movement from one rate of price increase to a new maintained higher level of price increase, but that there has been a periodic upwrd movement in the rate of inflation. There is no reason that this process has to continue. Policymakers have the power to prevent a permanently acclerating rate of price increase. It is true that more attention is being devoted to "how to live with ingation" rather than "how to fight inflation," but this is a very dangerous approach. A little inflation leads to a

\footnotetext{
Note: The views expressed in this article are the responstbility of the anthor and do not necessarily reflect the views of the Federal heserve System.
}

litde more infation which leads to a litule more inflation untl infation has become a major disruptive force in the economic as well as the social rabric of a country.

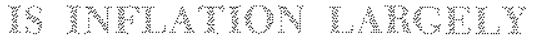

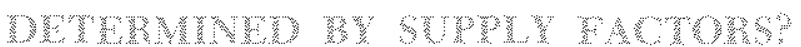

An exogenous decrease in the supply of one good will tend to (1) raise the price of that good, (2) raise the demand for and price of substitute goods, (3) lower the demand for complementary goods and hence put downward pressures on the prices of these goods. The way a maket econony adjusts to a change in supply conditions is through changes in relative prices and re-allocation of resources from one type of prom duction to another. Assuming no Govemment controls

\footnotetext{
Weonomists reter to two goods as substitutes if boh goods have many properties that satisfy the same prefurences of consumers; for example, was heat and electric hear, peblic transportation and automobles, a vacation in Emope and a vacation in the United States. Goods that are ased together are called complementary goods; for exanise, gatohe and antomobiles, tires and antomobles, European yacations and airline travel.
} 


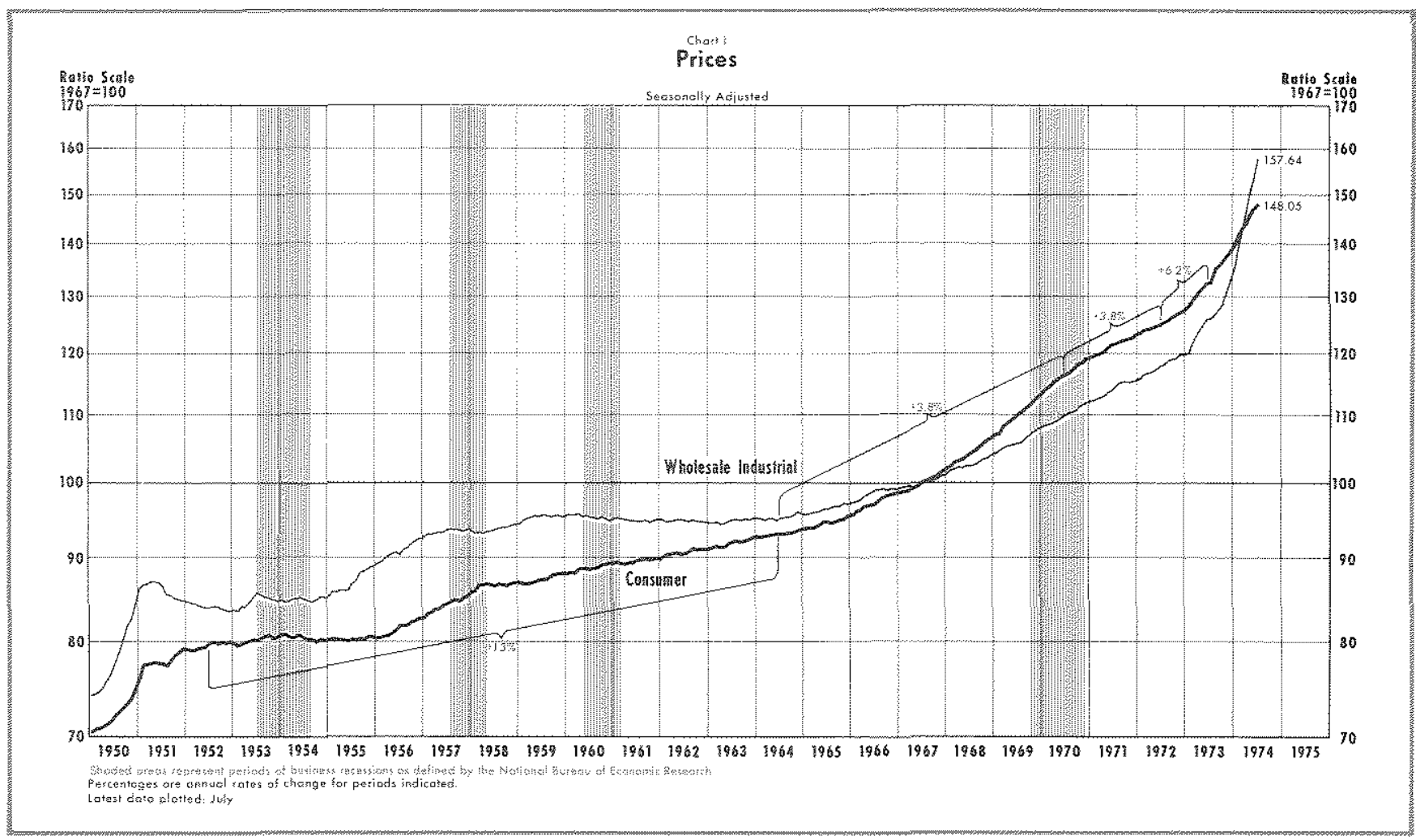

on prices, resources will be bid away from those industries producing complementary goods and will move into industries producing substitute goods. In* itially, the average price level will rise, assuming prices of complementary goods are not immediately flexible downwarl, and unemployment will temporarily rise since resources do not immediately move fally from producing complementary goods to producing substitute goods.

For a decrease in the supply of one good to cause a permanent increase in inflation, holding growth of total expenditures constant, would appear to require that the iten was so vital to production that no substitute existed or could be developed. In that case, reducing the supply of that good means that the potential growth of real output is reduced. This seems a highly unlikely case, except in the short-run. Man seems capable of finding a substitute good for almost any item. However, even if this were the case, the increase in inflation is not ultimately due to the reduotion in supply, but results from the fact that growth of total expenditures is not reduced along with the reduced growth of real output. If the growth of total expenditures is maintained, but the growth of real output is reduced, then prices will rise more rapidly. The monetary atutionties cannot affect the supply situation, but they can follow policies that reduce the growth of total expenditures.
Infiation began to develop in the United States long before any so-called supply-induced effects developed. For example, over the 1963-69 period real output rose at an average annual rate of 4.7 percent, compared to an average rate of about 3 percent over the previous ten years. However, from 1963 to 1969 the rate of inflation increased to a 3 percent annual rate, about double the rate of the previous ten years. ${ }^{2}$

Wo must look somewhere other than at supply factors for the underlying cause of inflation. The basic underlying canse of the inflation currently being experienced in the United States is simply that the trend growth of money has been accelerating over the last ten years, approaching a 7 percent rate on average over the last three years. This has resulted in a growh of demand for goods and services that is much greater than the long-term average growth of real output.

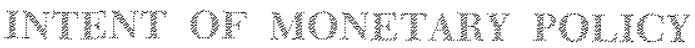

The current intent of monetary policy in the United States is to reduce inflation and avoid catsing a substantial medium-term rise in unemployment. In fact this is the same "intent" that has characterized mone-

Unless otherwise noted, all growth rates are computed on an average-of-year basis. 
tary policy since the middle 1960s. No member of the Federal Open Market Committee desired to have the rate of inflation, as measured by the consumer price index, rise from an average annual rate of about 1.5 percent over the period 1952-64 to an average annual rate of about 4 percent from 1964 through 1972 , or to see price increases accelerate to an average annual rate of over 6 percent during 1973, as shown in Chart I.

The basic force underlying the accelerating inflation in the United States has betn the accelerating average ammual growth of the money stock. As shown in Chart II, the growth of the money stock accelerated from about a 2 percent average amnal rate over the period $1952-62$ to about a 5 percent annual rate over the period from 1962 through 1970. Over the period 1962-70 the growth of the money stock followed a pattern of sharp accelerations followed by periods of sharp reductions in the growth rate (for example, in 1966 and from early 1969 to early 1970 ). Since 1970 the growth of money has reaccelerated to about a 7 percent annual rate. At the same time, real output has grown at an average rate of about 4 percent since 1962, somewhat faster than its average annual rate of about 3 percent recorded over the pre- vious ten years. With progressive accelerations in the rate of growth of money leading to a markedly faster growth of total expenditures, and with real output growing at only a slightly more rapid rate, prices rose at accelerated rates.

Again, I do not believe that any member of the Federal Open Market Committee desired the progressive upward movements in: the growth of money. From 1964 to 1973 the Federal Open Market Committee (FOMC) met 141 times and voted for a policy of restraint at seventy percent of these meetings. Only in 1967 and 1970 did the FOMC adopt a policy of ease at virtually every meeting.

Given that the intent of policy has not changed, why has there been a progressive rise in the average growth of the money stock and, hence, a progressive rise in infation? Three related factors appear to account for this situation. First, in the United States since the mid-1960s, there has been a sharp rise in the growth of Goverment spending. Since 1965, Federal Goverment expenditures have risen at an average annual rate of 10 percent, compared to about a 6 percent rate over the previous ten years. In 1966 and 1967 the major rise was the to defense spending

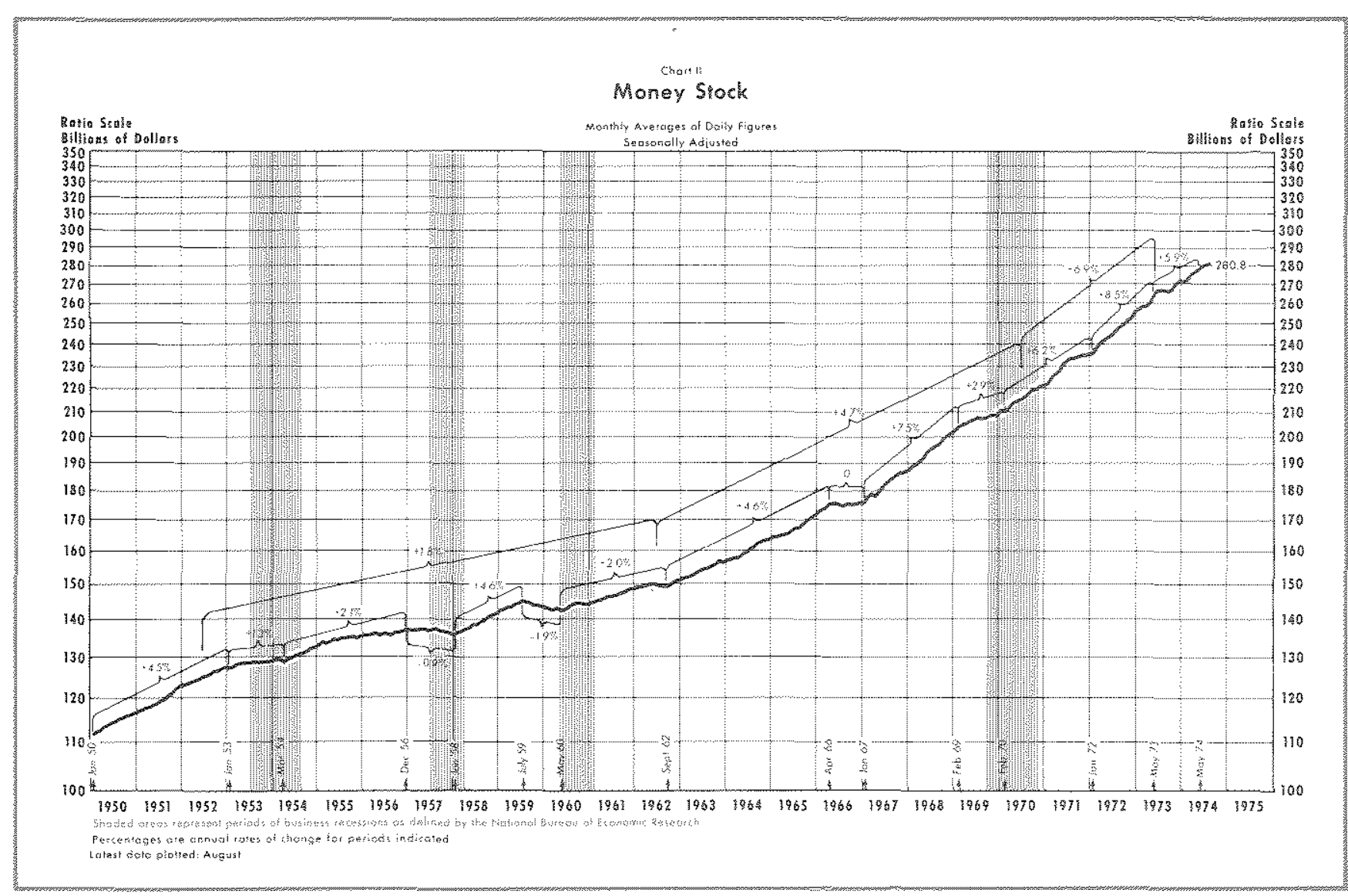


which rose 20 percent per year. llowever, since 1967 the growth of defense spending has been much slower, and actualy dechned from 1969 brough 1973. The rise in Federal Govermment expenditures smoe 1965 has primarily reflected the public srowing demands that the Govermment sector do nore in the way of social weltare programs. Since 1965 , Faderal nondefense expenditures have risen at a 12.6 percomt andual rate, compared to a 9.5 rate over the previous ten years.

Essentidy, the pullic has demanded that the Gow emment secton provide a larger flow of goods and services. However, while Govemment spending was rising, tanes were not raised enough to finance the increased expendtures. This brings us to the second Fotor. As a result of a rising spread between tax revenues and Govemment expenditures, the growth of the outstanding stock of Govenment securities ac celerated as the Govemment was forced to borrow to fnance its expenditures. Over the period of fiscal year 1966 thromgh hsol 1973, Federal Govermment expenditures exceded tax receipts by amost $\$ 98$ bilHon. The net result of deficif financing was upward pressures on maket interest rates.

This brings us to the third factor. The Federal he serve System traditiondy has been concemed with the stability of warest rates and with the "viability" of mancia makets. Consequenty, the Federal Re serve has tended to resist demand-determined move ments in therest rates and has always stood ready to offer subtential aid ho fhancial makets in thes of stress. The substantin rise in Govemment Anancing requirements was bound to put apward pressures on market inferes rates and put stress on fnancia mar kets. Essentally, the Govemment was attempting to acanire more funds than before though the credic makets, ant, assuming no change th the growth ot total crodin, oher demandew of credit wonld have had to be rationed ont of the market.

Anong the other demanders of credit was the housing industry. As market yells on Governent debt rose, hads were drawn out of savings and loan associations, the supply of tunds to finance housing idel, and morgage therest rates rose. Questons arose about the solvency of the mon mancers of morgage credit. These resuls, along with pressures on the firancing of state and loch govemments, developed qute eary in the infatonary process, and in 1966 cunnated in what has cone to be called "the credit crunch of 1968 ."

The Federal Reseve che under considerable citi cism for permiting the development of the "cunch" in 1966. However, although certain Federal Reserve policies probably added to the strain on fnancial markets at that time, the situation in 1966 rellected the attempt of fnancial markets to adjust to the added financing pressures from the Federal Govemment. The 1966 Fedem Reserve policy of resisting a substantial expansion in money and credit was an artempt to force the adjustment throagh fnancia markets. If the Govermment was going to get a larger share of real output, then some other sector had to receive a smaller share.

The Federal Reserve tried to hat the upward march of infation again in 1969. From February 1969 to February 1970 monetary policy actions slowed the Growth of the money stock to about a 3 percent rate. This led to the slowdown in economic activity in 1970 , and from about mid-1970 there was evidence of a slowing in infation. By the end of 1970 , the market yed on Treasury bils had fallen below 5 percent, compared to about 8 percent at the end of 1969. In the fist auarter of 1971, yields on longutem corporate bonds had eased to about 7.25 percent, compared to about 8 percent in late 1969.

However, after early 1970 , Federal Reserve actions resulted in a reacceleration in the growth of the money stock. From 1970 through 1973, Federal Reserve credit grew at an average ammal rate of 9.5 percent and the monetary base grew at a 7.7 percent rate. On balance, since early 1970, money has grown at about a 7 percent rate. Athough infation continued at a slower rate throngh hate 1972, how much of this was due to the lagged effect of the previons slowing of money on prices extending into late 1972 is open to question. In August 1971 a birly comprehensive set of price and wage controls was instituted in the Unted States. The lag in the response of prices to the reaccleration of money probably reflected the effect of these price controls. Sooner or later the up. ward pressure on prices had to surface, and price controls appear to have only delayed the upward thust of prices. The main result of the various phases of price consols was the distortion in supply conditons that the Unted States is stll experiencing.

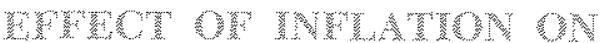

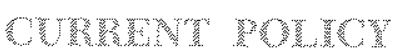

Infation aftects current monetary policy because infation afects interest rates and hnancia market. Also, accelerating infation, when yined with price controls, tends to raise questions about the predictive performance of econometric models that are used to forecast 


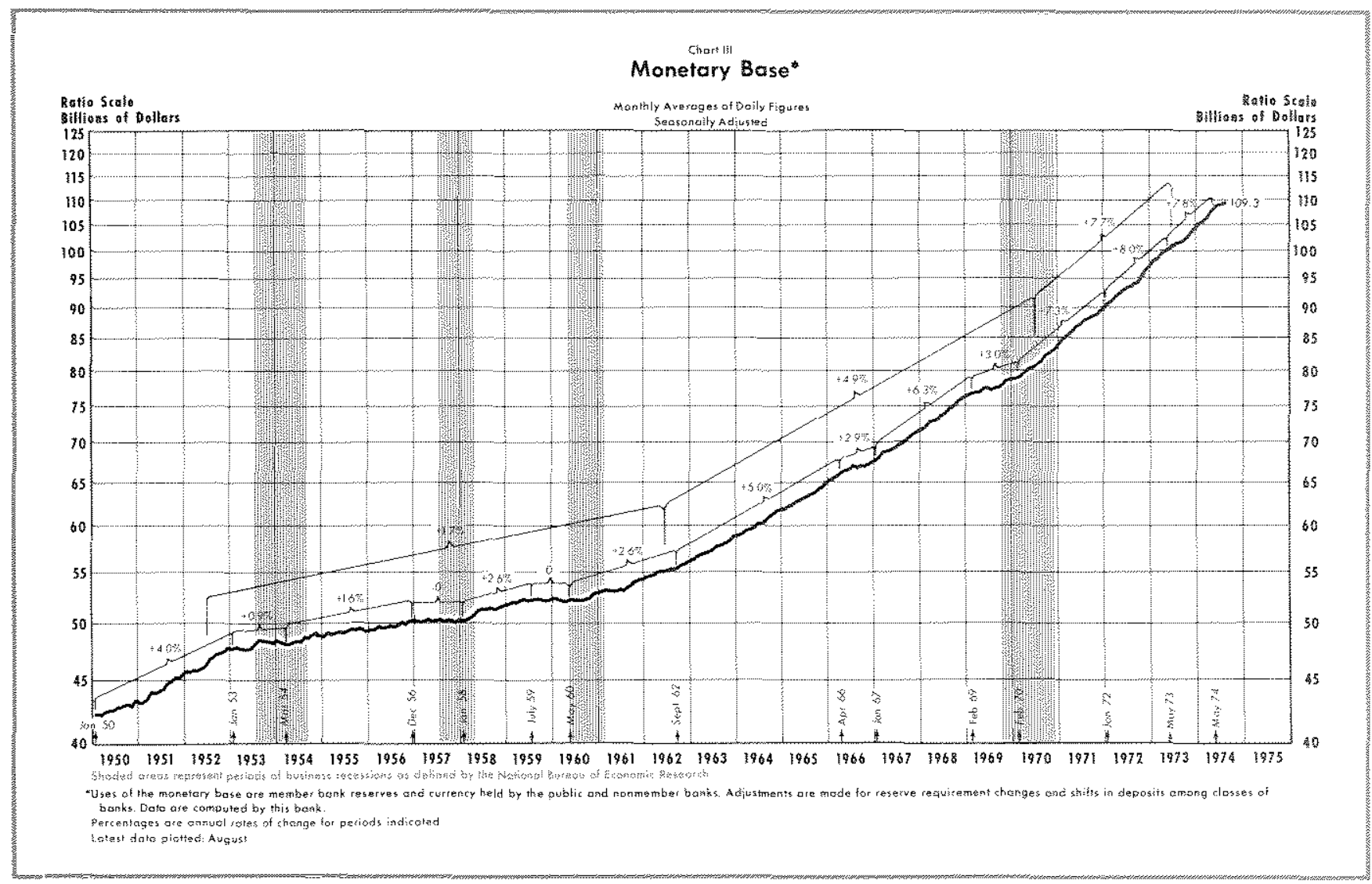

the response of the economy to policy actions. A further effect has been the suggestion by some observers that "real" instead of nominal quantities should be used as indicators of the effects of policy notions.

Recently the United States has been experiencing levels of interest rates that are "high" by historical standards. However, it would be hard to ascribe these high interest rates to "ught" monetary policy, As shown in Chart III, over the last three years the monetary base has grown at a 7.7 percent rate, compared to about a 5 percent rate from 1962 through 1970 and less than a 2 percent rate over the 1952.62 period. Bank credit has grown at about a 13 percent fate since 1970 , compared to a 7.6 percent rate over the previous five years, and about a 6 percent rate from 1955-65. These growth rates indicate that Federal Reserve actions have resulted in a large enough growth of the monetary base to support a substantially more rapid expansion of bank credit than in previous periods.

The increase in the monetary base predominantly reflected the fact that the Federal Reserve System purchased a large volume of Govermment securities and the Treasury monetized the proceeds of the May 1972 and October 1973 changes in the official price at which the U.S. gold stock is yalued. The monetary base averaged $\$ 20$ billion higher in 1973 than in 1970 , the Federal Reserves holdings of Govermment securi ties averaged $\$ 17.8$ billion more in 1973 than in 1970 , and the Treasury's actions subsecuent to the two offictal revaluations of the U.S. gold stock adced $\$ 2$ billion to the monetary base.

A central bank policy of buying Goverment dobt and providing the monetary base for a rapid expansion of credit has the initial efect of holdmg interest rates below what they would be in the absence of steh a policy. However, the growth of the monetary base detemines the growth of the money stock. The close relationship between accelertions and deceler. tions th the growth of base and money call be seent by comparing Charts II and III. Therefore, a policy of attempting to resist movements in market interest rates also leads to a rapid expansion of the amount of money balances which andividuals must absom into their weath portfolios. From 1970 to 1973, the money stock grew on the average at abont a 7 percent anmal rate. This is more than three times as fast as over the 1952.62 period of slowly rising prices. As discussed earlier, the rapid growth of money led to a progressive upward movement in the rate of change of prices and this led to a growth in the demand for credit. 
Today's high levels of interest rates largely reflect the accelerating rate of inflation in the United States. When the current rate of inflation is taken into consideration, interest rates are not unusually "high." As shown in Chart $W$, relative to the rate of inflation, adjusted yields on Corporate AAA bonds are currently lower than any time within the last eight years, with the exeeption of early 1971. Although long-term market interest rates have been rising sharply since early 1973, the adjusted yield has been falling since about mid-1973.

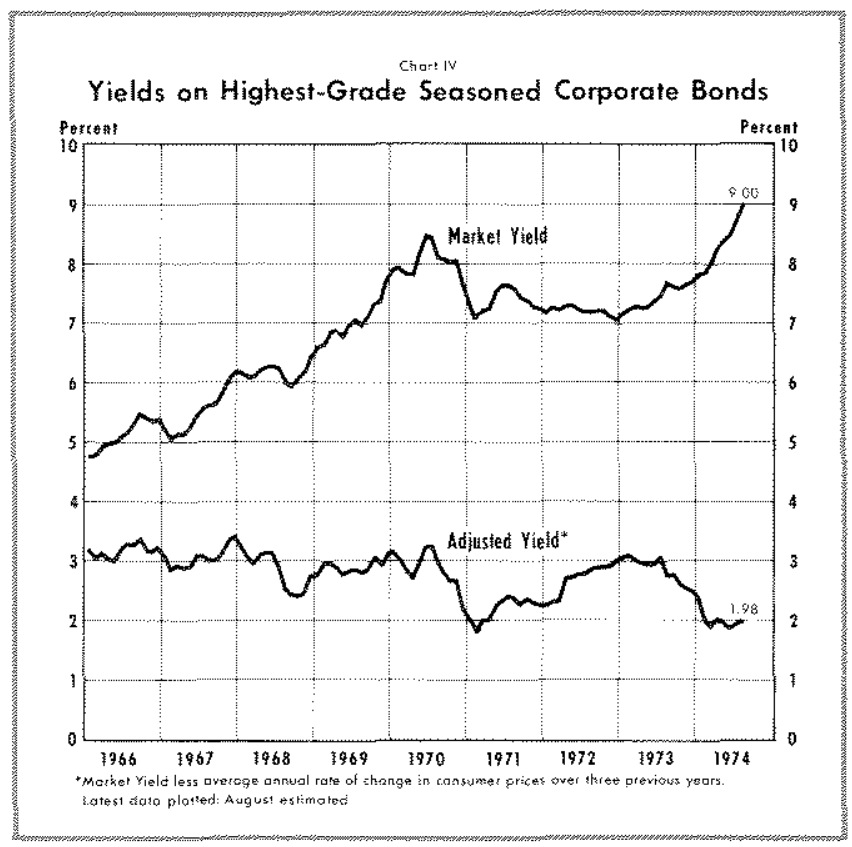

Through the middle of 1974 the Federal funds rate, the key interest rate used in short-run operating strategy, has risen sharply. However, there is some question as to whether the Federal funds rate has risen because the Federal Reserve pushed the rate up, or in spite of Federal Reserve actions. In times of rapid increases in the demand for credit, it becomes almost impossible for the Federal Reserve to hold interest rates constant. The more vigorously the Federal Reserve tries to bold interest rates down, the more rapidly the monetary base grows and, consequently, the more rapid the growth in the money stock.

An increased rate of growth of the money stock appears to have two effects on expectations of financial market participants. First, they have learned by experience over the last $8-10$ years that a maintained faster growth of money means a higher rate of inflation, and that means higher interest rates. Also, financial market observers have some idea about the Federal Reserve's desired growth path for the money stock. When they observe the money stock growing faster than what they think is the Federal Reserve's intent, then they expect that the Federal Reserve will have to tighten policy, and hence expect higher interest rates, at least in the immediate future.

To restrict the growth of the money stock in periods of rising demands for credit, the Federal Reserve must raise its target range for the Federal funds rate ahead of the market determined level. If increases in the target range for the Federal funds rate lag the market-determined rate, then the money stock will accelerate, even though the Federal funds rate moves upward quite rapidly.

Central bankers must be extremely wary of statements that, because interest rates are high, money is tight or monetary policy actions are restrictive. Such statements exhibit a fundamental confusion between money and credit that can be fatal for attempts to slow inflation. Interest rates are the price of credit, not the price of money. The reason the price of credit is high is not because money is tight, but because it has been too easy. The previous rapid growth of money has generated an expected rise in demand and rising prices and, hence, growing demands for credit. Comparing Chart $V$ and Chart II, it can be seen that, empirically, it is the case that low interest rates, not high interest rates, follow a period of tight money.

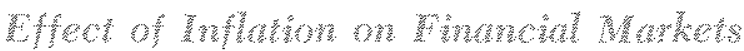

An important part of the financial sector of the United States is composed of financial intermediaries which borrow short-tem and lend long-term. These institutions are primarily engaged in financing mortgage credit demands, and consist of institutions such as savings and loan associations, mutual savings banks, life insurance companies, and real estate inyestment trusts. For these financial intermediaries it is not the level of the term structure of interest rates that is of primary importance, but variations in the level.

In an accelerating inflation, maket interest rates on assets competitive with savings deposits are rising, and savings institutions must raise the interest rates they pay to borrow short-term or face an outlow of deposits. Under such circumstances, the savings institutions come under considerable pressure. The cost of borrowing short-term rises rapidly, but the bulk of their portfolio of assets is locked into nonliquid long-term mortgages that have a fixed interest rate.

The smooth operation of financial markets is also adversely affected in other ways by inflation. For 


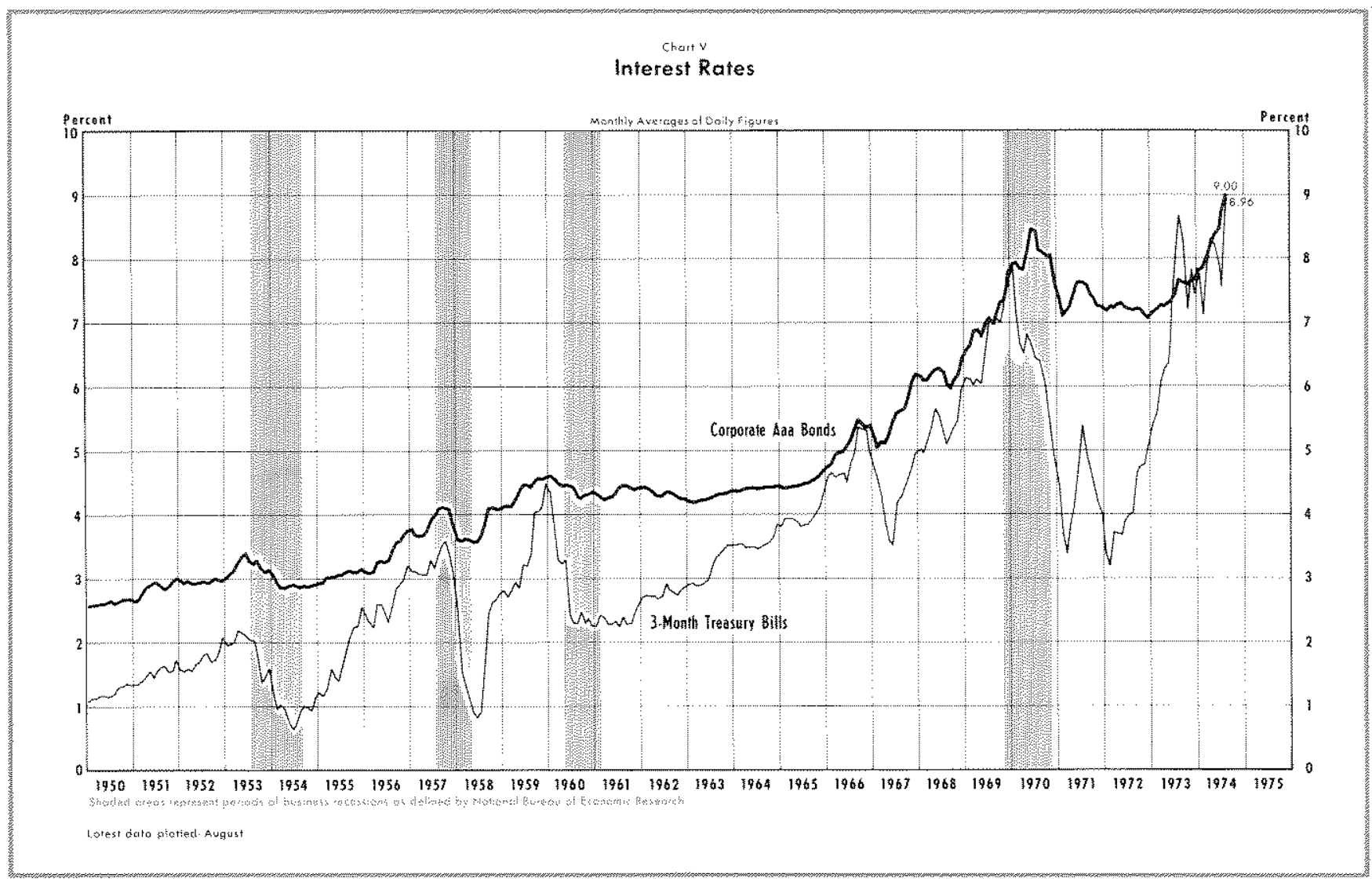

example, bond dealers are reluctant to take positions in long-term securities, because with rapidly rising interest rates, there is an increasing risk of capital loss.

A potentially serious situation can develop if a few large fmancial institutions misread the future path of interest rates. Suppose a lender expects that interest rates will fall in the next six months. In late 1973 and early 1974 several respected financial advisory servtces were forecasting falling interest rates. The lender will then try to borrow short-term in order to extend. his long-term assets. For example, a bank would try to increase its borrowings in the Federal funds market and sell short-term large certificates of deposit, while extending longer-term business loans and purchasing longer-term Government securities. If, however, shortterm rates rise very rapidly, instead of falling as predicted, then our hypothetical bank will incur losses.

From early December 1973 through late February 1974 short-term interest rates in the United States fell while longer-term interest rates continued to rise. From late November to late February, large commercial banks increased their term business loans by about $\$ 1.3$ billion and their holdings of Goverment securities with over 5 years to maturity by about $\$ 600$ million. Over the same period, the volume of large certi- ficates of deposit outstanding increased by about $\$ 2$ billion and the average net purchase of Federal funds rose by $\$ 2.6$ billion. In early March, shont-term interest rates began to increase and over the following months rose very sharply. The market rate on 90 day certificates of deposit rose over 300 basis points from late February to mid-May, and the rate on Federal funds rose over 250 basis points. Therefore, the cost to an individual bank of obtaining short-term funds to finance term loans made during late 1973 and early 1974 and to carry securities purchased during that time rose substantially in the following three months.

This discussion is not an attempt to picture the financial system as "inherently unstable." It is intended to show that attempts by the monetary authorities to resist demand-determined upward pressures on interest rates, except in the very short rum, do not result in easing financial market pressures. As the monetary authorities expand the monetary base, money expands and ultimately there are greater upward pressures on interest rates as the demand for credit increases. Ultimately, such a policy results in greater, not less, strain in the financial markets, and makes the problems encountered by the central bank when it attempts to slow inflation that much greater. This is 
especially true because sone financial operators still appear to believe that the monetary anthorities can hol market interest rates below the level determined by fundamental marlet factors. The only way to oventualy acheve lower interest rates is to slow the growth of money and credit. However, this implies additional temporary upward pressures on interest rates, and huther raises the spector of another "credit crunch". These factors further illustrate that, the longer infla thon is permitted to develop, the more diffoul it is to stop.

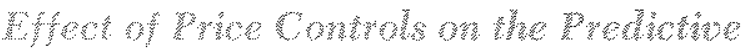

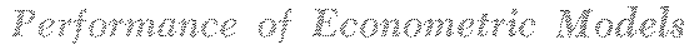

It is very difficult to judge the effect of inflation on the predictive performance of the Federal Reserve Bank of St. Louis model, as well as any other model. During most of the period since Atigust 1971 the U.S. economy has been subject to various types of price controls. These controls probably distorted the be havior of prices relative to what they would have been without controls. Under these conditions, econometric models are only a guide to the upward pressures that are building on prices.

For example, the St. Louis model overestimated the reported rise in prices during the period of price controls, but since the lifting of most price controls, it has underestimated the increases in prices. On balance, the model has fairly accurately projected the long-run behavion of prices. As shown in Table 1 , fitting the model through the second quater of 1971 , the last full quarter before price controls, and projecting throngh 1973 shows that the model estimated about a 5 percent growth of the price deflator from $1 / 71$ though $T / 73$. Actual reported prices rose at a much slower rate during the price control period, then accelerated as price controls were lifted.

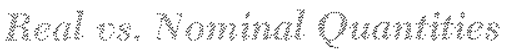

The use of real instead of nominal quantites as guides to monetary policy can be extremely dangerous. First, all that policymakers, as well as other economic agents, observe is nominal interest rates and money balances. They never observe real interest rates or real money balances, and economists cannot agree on how to accurately measure these real quan tities. This is not to say that the rate of infation does not enter into the publics decision to borrow, nor

\footnotetext{
3This section draws heavily on the article by Denis $S$, Karnosky "heal Money Balances: A Misleading Indicator of Monetary Actions," this Roview (February 1974) pD. $2^{2} 10$.
}

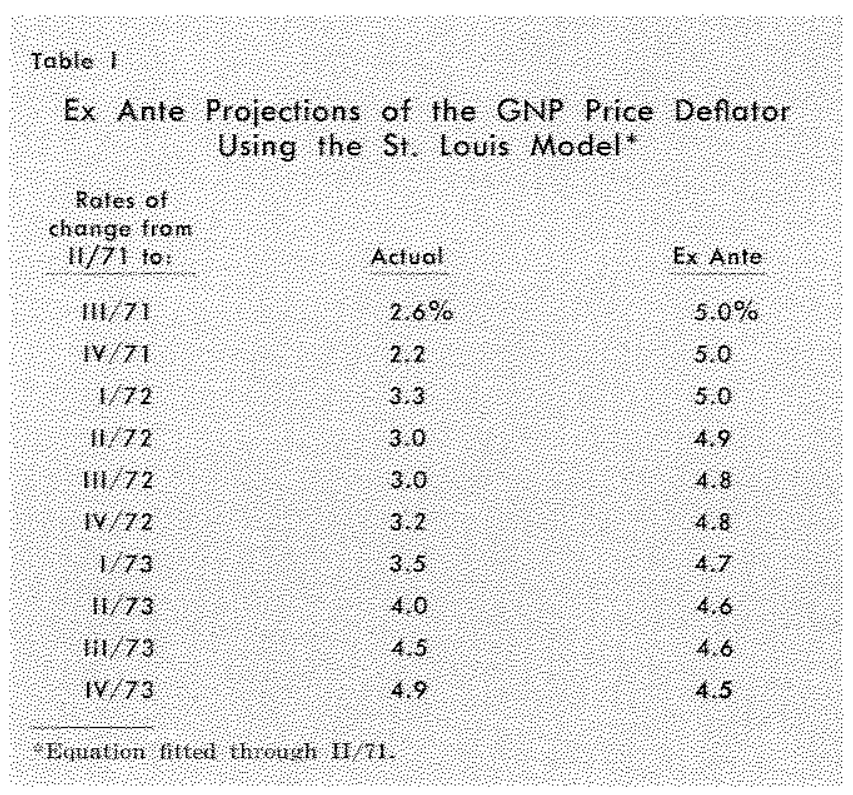

their decision as to the amount of money balances they desire to hold. However, the crucial distinction for central bankers is that, while individuals adjust their money holdings to prices, for the economy as a whole, prices adjust to the amount of money. Secondly, the ratio of money to some price index is a faulty indicator of tightness or ease of monetary policy because this ratio is determined by the public and is ultimately beyond the control of the monetary authorities. Monetary actions have only a temporary effect on real money balances.

There are five periods from 1955 to 1973 when the ratio of money to commodity prices declined for two quarters on more: 1955-57, 1959-60, 1966, 1969, and 1973. Prior to 1973, each period in which "real balances" declined for two quarters or more was followed by a significant slowdown in economic activity, ranging from the 1966-67 mini-recession to full-scale recessions in the other periods.

In 1955-57, 1959-60, 1966, and 1969 a large portion of the decline in real balances reflected a sharp drop in the rate of growth of the money stock below its trend. The deceleration in money growth in 1973 was not as abrupt. Instead, the indicated decline in "real balances in 1973 reflected, in large pat, the reported acceleration of inflation.

Since the adjustment of prices to a change in the trend rate of money growth is estimated to take from four to six years to complete, it is probable that the economy is still adjusting to the accelerated rate of money growth over the last three and one-half years. Supporting evidence for this contention can be found in the movement of interest rates in 1973 . 
The inflation of last year, instead of threatening to restrict aggregate demand by eroding real money balances below desired levels, reflects instead the efforts of the public to dispose of excess money balances. On the basis of past experience, if the money stock continued to grow at an average rate of close to 6.5 percent, such as since early 1970 , this adjustment would continue at least through 1974.

The arguments which contend that monetary policy is restrictive, on the basis of the recent decline in "real money balances," imply to some analysts a recommendation to policymakers to increase the rate of money growth above the rate of inflation in order to restore the growth of real balances. Both theoretical analysis and the experience of other countries indicate that there are few more dangerous courses of action that any monetary authority could undertake.

A further increase in the rate of money growth, above its current trend rate of about 6.5 percent would only generate pressure for further inflation. It is not possible to avoid the adjustment of real money balances to the level desired by the public by increasing the rate of money growth.

One extreme example of the futility of a policy of trying to make money grow fast enough to prevent desired real balances from falling is given by the German experience in the early 1920s. By late 1923 tax receipts of the Geman government were covering less than one percent of its expenditures. To finance its expenditures, the government borrowed from the Reichsbank, which simply tumed on the printing presses. The majority of trained economists in Germany refused to believe in a chain of causation running from the growth of the money stock to the growth of prices. Rudolf Havenstein, President of the Reichsbank, tended to believe that the rise in prices created a need for money on the part of businessmen and the government which was the Reichsbank's duty to meet, and which would have almost no harmful effects on the economy. When complaints of "shortages" of money arose, despite the issue of denominations as large as 100 trillion marks, Havenstein seriously expressed hope that new high-speed currency printing presses soon to be installed would overcome the shortage. ${ }^{4}$

4The material in this section draws ipon Leland $B$, Yeager International Monetarty Relations (New York: Harper and Row Publishers, 1966), pp. 269-72), and quotes from the League of Nations Study, The Course and Control of Inflation, See also, Frank D. Graham, Exchange, Prices and Production in Hyper-Inflation: Germany 1920-23 (New York: Russell and Russell, 1930).

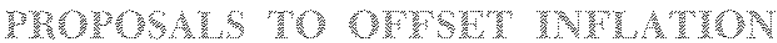

Recently, proposals for tying future payments in contracts to some price index (so-called indexing) and explicit payment of interest on demand deposits have been suggested as ways of removing some of the losses associated with unexpected future price movements.

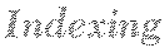

The use of indexing has increased in the U.S. economy as inflation has accelerated. Recently, the U.S. Congress decided to tie social security payments to the consumer price index, and more wage contracts are being written with cost of living escalator clauses, not only for wages, but also for pensions. " However, these actions represent only partial indexing. At present, it does not appear that the U.S. is likely to adopt a full economy-wide pattem of indexing. Especially difficult problems would arise when indexing such items as interest rates. For example, attempts to develop variable interest rate mortgages have met with less than enthusiastic support.

Partial indexing probably creates more problems than it solves. Groups whose flow of payments are linked to some price index will be far less willing to support efforts to halt inflation. This is especially true because policies taken to slow inflation also involve some short-run rise in unemployment. It is one thing to explain the reason for tighter fiscal and monetary policy to an individual by pointing out that increased Government spending financed by money creation results in a fall in his real income; it is much more difficult, however, to convince him of the merits of tighter fiscal and monetary policy when his income is tied to a price index.

The actual implementation of generalized indexing presents considerable practical difficulties. What price index will be chosen? Who will decide the way to index prices? What about outstanding contracts? How do you index profits? For example, there has been considerable furor raised over recent attempts to broaden the coverage of the consumer price index. Also, some aspects of indexing would require substantial changes in tax laws, for example, tying the personal exemption to inflation and taking the effect of inflation into account in computing depreciation

\footnotetext{
For about 5 million workers, changyes in their incomes are tied to changes in the consumer price index. Receipts of an additional 3 million food stamp recipients and all social security recipients are also affected by changes in the CPI.
} 
and capital gains, Also, all state usury laws would have to be abolished and regulations on payment of interest on time and savings deposits wolld have to be removed or modified. The effect of many indexing proposals would be to hold the Government's tax reverues constant as inflation increased. In inflation the cost of existing Govermment opentations would rise, and if there was no cut in Govermment operam tions, deficit financing wonld increase. These decisions move us from the field of economic theory into the area of politics and bureaucracy. Having observed the fiasco of wage and price controls, the author is none too confident that the Govemment can resist the temptation to selectively intervene in the development of an indexing system, and hence is doubtful that a viable system of indexing can be developed.

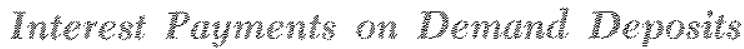

Generally, the arguments that have been advanced for prohibition of interest payments on demand deposits in the United States are not supported by empirical evidence. Currently, commercial banks pay an implicit rate of interest on demand deposits: the cost of servicing demand deposits is greater than service charges by banks. This probably leads to some inefficiency in allocation of resources that could be avoided if banks paid a maket-ketermined interest rate on demand deposits and charged depositors the full cost of bank services.

However, as a practical matter, a wiłespread movement in support of payment of interest on demand deposits does not appear likely in the near future. Changes in legislation would be required to permit commercial banks to make explicit interest payments on demand deposits, and there does not appear to be wide enoagh support for these changes from any well-organized political group.

\section{GONCLISIONS}

The way to reduce inflationary pressures in the United States economy is to slow the growth of the money stock. On an average-of-year to average-ofyea basis, the money stock grew at about a 7 percent rate from 1970 to 1973 . It seems to be a generally accepted proposition in economics that the growth of prices adjusts to the growth of money over ar extended period of time. Therefore, if the 7 percent rate of money growth experienced over the last three years in the United States is maintained, this implies our economy will adjust toward a long-run 6-7 percent rate of inflation. The recent surge in prices reflects party an adjustment to the removal of price controls, and party the continued upward adjustment to the average growth of the money stock.

The only way to halt the upward movement of interest rates is to slow money growth. If our economy is being lorced to adjust to a $6-7$ percent amnual rate of inflation, then nominal interest rates on long-term bonds will not remain at around 8 percent but probable will rise to $9-10$ percent.

In the United States the central bank can halt the growth of the money stock. The Federal Reserve, through its open market operations, can control the growth of the monetary base, and hence control the growth of the money stock. The Federal Reserve is on record as having the intent to slow the growth of the money stock. The intent of policy is not to cause a dramatic halt to money growth, because of the short-run effects on employment, but to gradually reduce the trend growth of money.

Whether or not this "intent" is realized will crucially depend upon (1) the Govenment's willingness to exercise restrant in its spending, and (2) a willingm ness on the part of the Federal Reserve to allow market interest rates to rise temporarily to high levels. As discussed earlier, nominal interest rates that seem extremely high by historical standards are not high when the current rate of mflation is taken into account.

It is useful to refer again to the German experience of $1920-23$ to see how excessive govermment spending and central bank creation of money becone bound together, and how diffictult it is for any central bank to pursue a monetary policy that rums counter to the govermment's fiscal policy.

This fundamental cause, insofar as it does not rest on the balance of payments, is . . the boundless growth of the floating debt and its transformation into the means of payment. . . hhrough the discounting of the Reich Treasury bills and the Reichsbank.

Here too the Reichsbank is alleged to be guilty, because it has not opposed the Reich govermment and fiscal administration by refusing to continue the discounting of Treastury bills. This reproach is also unjustified and completely misjudges the actual situation. The Reichsbank has done all it could do with any chance of success. For years . . it has continually called attention to these conditions and clemanded a remedy in the most serious and urgent way, but it was not in a position to stop the discounting of Treasury bills as long as the Reich had no other available means to cover its deficit, and as long as all groups in the legislature were not fully convinced that such means absolutely have to be found. For the Reich must live, and real renunciation of discounting in the face of the tasks set by the budget ... would have led to chaos. The threat of a general refusal to discount Treasury bills would have been 
nothing but a futile gesture. Only very recently, under pressure of dire necessity, have all groups in the legislature been convinced . . . that fiscal policy abm solutely must be based upon adequate sources of income. ${ }^{6}$

"Rudolf Havenstein, "Defending the Policy of the Reichubank" (Address to the Executive Committee of the Reichsbank, August 25, 1923) in Fritz K. Ringer, The German Inflation of 1923 (New York, Oxford University Press, 1969), pp. $93 \times 96$.
Somehow the pablic must be convinced that once inflation has gained a fim foothold there is no painless way to hat it. Also, the public must reatize that goods provided by the govermment are not free goods. If the govemment sector absorbs and redistributes a larger segment of real output, then the private sector must be satisfied with a smaller share. Unless these fundamental facts are understood, then the good "intent" of policy will probably not be realized.

\section{Author's Note}

Since this paper was prepared in May 1974, there has been a retision of money stock data for the first half of 1974. The revised data suggest that monetary actions in the United States have been directed at reducing infation with a minimum impact on employment. For example, on a quarterly-average basis, from second quarter 1973 to second quarter 1974 , the money stock grew about 6 percent. This represents a moderate reduction in the average growth of 7 percent recorded from first quarter 1970 to second. quarter 1973. It also represents a move away from the pattern of accelerating money growth experienced over the period since early 1970.'

Since May, however, inflation has continued to accelerate at an alarming rate, and interest rates have continued to rise. For example, from December 1973 to July 1974, consumer prices rose at about a 12 percent rate, and most forecasters see little reduction in the rate of inflation through the remainder of 1974 . Yields on corporate bonds are up about 70 basis points over their May levels, mortgage rates have risen, the prime commercial bank loan rate is up 50 basis points from the end of May, and commercial paper rates and Treasury bill rates are up over 100 basis points.

While prices and interest rates have continued upward, real output has declined. Over the first two quarters of 1974, GNP in constant dollars decreased at a 4 percent annul rate. This continues the slowing in real output growth that began in early 1973. For example, from the first to the fourth quarter of 1973 ,

From $1 / 70$ to $1 / 72$ money grew at a 6.3 percent rate, then from $1 / 72$ to $1 / / 73$ money grew at an 8.1 percent rate. real output grew at about a 2 percent rate, compared to a growth rate of 6.7 percent from fouth quarter 1970 to first quarter 1973.

In the author's opinion the recent sharp accelera tion in inflation and the slower growth of real output must be viewed in the long-run context of the whole period since late 1970 when the most recent expansion began. On balance, since the fourth quarter of 1970 , the general price index has risen at a 5.7 percent annual rate, about in line with what would be expected from a 6.5-7.0 percent average grouth rate of money. Real output has risen at about a 4 percent average rate, about in line with the longer-run growth of the productive capacity of the economy. By looking only at the performance of the economy in the last one and one-half years, one gets a distorted view of the performance of prices and output. Over the period prior to early 1973, real output grew at a rate far in excess of its long-run potential growth, and prices were artificially held down by wage and price controls. The recent sharp surge in prices reflects the adjustment to the trend growth of money, following relaxation of wage and price controls, and special situations in some domestic and foreign markets. These adjustments may well continue through 1974.

The recent performance of the economy has led some people to suggest that fiscal and monetary policy be directed at stimulating economic activity. Such a policy response might well frustrate the intent of slowing inflation without substantially affecting the rate of growth of employment. The criterion of patience must be added to the other criteria for successful achievement of an intent to slow inflation.

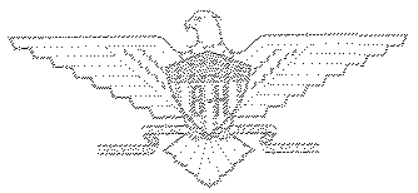

